\title{
Loss and damage from flooding in the Gambela region, Ethiopia
}

\author{
Alemseged Tamiru Haile* \\ International Water Management Institute, \\ P. O. Box 5689, Addis Ababa, Ethiopia \\ E-mail: A.T.Haile@cgiar.org \\ E-mail: alemsegedtamiru@yahoo.com \\ *Corresponding author
}

\section{Koen Kusters}

WiW - Global Research and Reporting, Eerste van Swindenstraat 391-I, 1093 GB Amsterdam, the Netherlands

E-mail: kusters.koen@gmail.com

\section{Negash Wagesho}

Arba Minch Institute of Technology,

Arba Minch University,

P.O. Box 21, Arba Minch, Ethiopia

E-mail: nwagesho@gmail.com

\begin{abstract}
In this article, we explore the ways in which people in the Ethiopian Gambela region dealt with the extreme flood that occurred in 2007, with specific attention to the associated loss and damage, i.e., the impacts that people were not able to avoid through preventive and coping measures. We found that all of the 431 surveyed households took preventive measures such as the construction of boundary walls, harvesting premature crops and digging drainage ditches to divert the flood away from croplands. However, these could not prevent widespread negative effects such as damage to houses and crops, the outbreak of diseases, and loss of livestock. To deal with the adverse effects, $50 \%$ of the respondents relied on the help of relatives, neighbours or friends for food and money. Such assistance appeared crucial. People were, however, worried about over-using their social networks, especially with floods occurring more regularly. Widening people's agricultural and non-agricultural options, for example through investments in micro-finance services and irrigation systems, will help to increase their coping capacity.
\end{abstract}

Keywords: flood prevention; coping; impact; loss and damage; social capital; Baro River; Itang; Gambela; Ethiopia.

Reference to this paper should be made as follows: Haile, A.T., Kusters, K. and Wagesho, N. (2013) 'Loss and damage from flooding in the Gambela region, Ethiopia', Int. J. Global Warming, Vol. 5, No. 4, pp.483-497. 
Biographical notes: Alemseged Tamiru Haile is a Hydrological Modeller with a PhD in Spatial Hydrology from the University of Twente in the Netherlands. $\mathrm{He}$ is currently a Researcher at the Nile-East Africa Office of the International Water Management Institute (IWMI).

Koen Kusters is a Human Geographer with a $\mathrm{PhD}$ in Environmental Sciences from the University of Amsterdam. He currently works as a Researcher and Writer with $\mathrm{WiW}$ - Global Research and Reporting, based in Amsterdam, the Netherlands.

Negash Wagesho is currently working as an Assistant Professor in the Department of Water Resources and Irrigation Engineering at Arba Minch Institute of Technology, Arba Minch, Ethiopia. He earned his $\mathrm{PhD}$ in Hydrology from the Indian Institute of Technology, Roorkee. He has about ten years teaching and research experience in the fields of hydrology, irrigation engineering and GIS and has published couples of papers in international journals related to hydrology.

\section{Introduction}

River floods pose a serious threat to millions of people living in river basins worldwide. At the national level, extreme floods may bring back development by some years (Pauw et al., 2010) and threaten national food security (Del Ninno et al., 2003). At the household level, a flood may leave people without shelter (Hernández-Guerrero et al., 2012), limit possibilities to get involved in economic activities (Linnekamp et al., 2011), and may increase the burden of diseases (Nyakundi et al., 2010; McCann et al., 2011). The severity of flood impacts may further increase in the future due to climate change. In many places, climate change will not only manifest itself as a gradual change in average conditions, but also as a change in the frequency and intensity of extreme events, such as heavy rainfall or drought, or periods of extreme heat or cold (IPCC, 2007).

Related to people's responses to climate change, we differentiate between adaptation, i.e., long-term responses to gradual changes, and coping, i.e., short-term responses to unusual events. The adoption of coping measures to deal with extreme events may facilitate the long-term adaptation to increased frequency and intensity of such events (Burton, 1997), but coping measures may also increase people's vulnerability to climate change (Smithers and Smit, 1997). Selling assets, for instance, could help households to immediately deal with the impact of an extreme weather event, but it also erodes their asset base. Both the level of exposure to the hazard and the socio-economic conditions of the affected households determine how people cope with unexpected disturbances. Through analysis of a coping index, Lazarus (2011) showed that differences exist in the way people respond to changes in the environment. The type of coping measures and their effectiveness in dealing with flood impact depend on enabling attributes such as education, income, and occupation.

There is a need for empirical evidence from field-based case studies to understand how people are adapting to gradual changes and coping with extreme events, and how this may affect their future livelihoods (Warner et al., 2012). So far, most adaptation and 
coping studies in Ethiopia have focused on droughts. Conway and Schipper (2011), in a study on climate risks in Ethiopia, emphasised the need to shift from a disaster-focused view to a long-term perspective, which emphasises livelihood security and vulnerability reduction. McGuire and Sperling (2009) assessed the effect of seed aid on local coping strategies in Ethiopia after drought. Based on a comparative assessment of adaptation strategies by farmers in Ethiopia and South Africa, Bryan et al. (2009) advocated the need to support adaptation by increasing access to information, credit and markets, and making a particular effort to reach small-scale subsistence farmers. Gray and Mueller (2012) showed that severe drought has often resulted in increased migration from the Ethiopian highlands to cities.

Although there have been several studies on the ways in which people deal with droughts in Ethiopia, studies on floods - and how people cope with them - are noticeably missing, while floods constitute a severe and possibly increasing risk to many people in the country's river basins. In the past decade, frequent and severe floods have affected many regions in Ethiopia (Woube, 1999; Tarekegn et al., 2010). The lowlands of Gambela region, located in the southwest of the country, are among the most flood prone areas. Recurrent floods due to overflow of the Baro River create favourable conditions for crop cultivation and livestock keeping, but in the case of an extreme flood, it threatens the lives and livelihoods of the people. The floods thus represent both a blessing and a curse to the local people. The flood frequency and magnitude in the region has increased during the last decade (Abaya et al., 2009). Major recent floods in Gambela include those in 2006, 2007, 2010, 2011 and 2012, causing the loss of lives and livelihoods. Climate models predict an increase in rainfall extremes over East Africa, which is likely to increase the frequency of extreme floods in Gambela in the future (IPCC, 2012).

This study explores the ways in which people deal with extreme floods in the Itang area of the Gambela region. We also look at the degree to which their measures are enough to avoid loss and damage. Loss and damage is defined by Warner et al. (2012) as negative effects of climate variability and climate change that people have not been able to cope with or adapt to. In addition to people's coping measures to deal with extreme floods, we also explore people's preventive strategies and the extent to which they are sufficient. The article specifically focuses on the ways in which rural households have dealt with the extreme flood that took place in 2007, which was considered by the community as the most severe flood of the last ten years.

\section{Study area}

This study was conducted in the Itang area of the Gambela region, located in the southwestern part of Ethiopia (Figure 1). The Itang area has a population density of about 20 people per $\mathrm{km}^{2}$. It covers $2,188 \mathrm{~km}^{2}$ and had a total population size of approximately 42,000 in 2011. All except one of the 21 villages (kebeles) in Itang are located in the floodplain of Baro River, which is the widest river in Ethiopia. It originates from the highlands in the southwest part of Ethiopia and flows across the low lying plains in the Gambela region of Ethiopia into the Republic of South Sudan, where it is known as the Sobat, before flowing into the White Nile River. 
Figure 1 Map of the study area (see online version for colours)

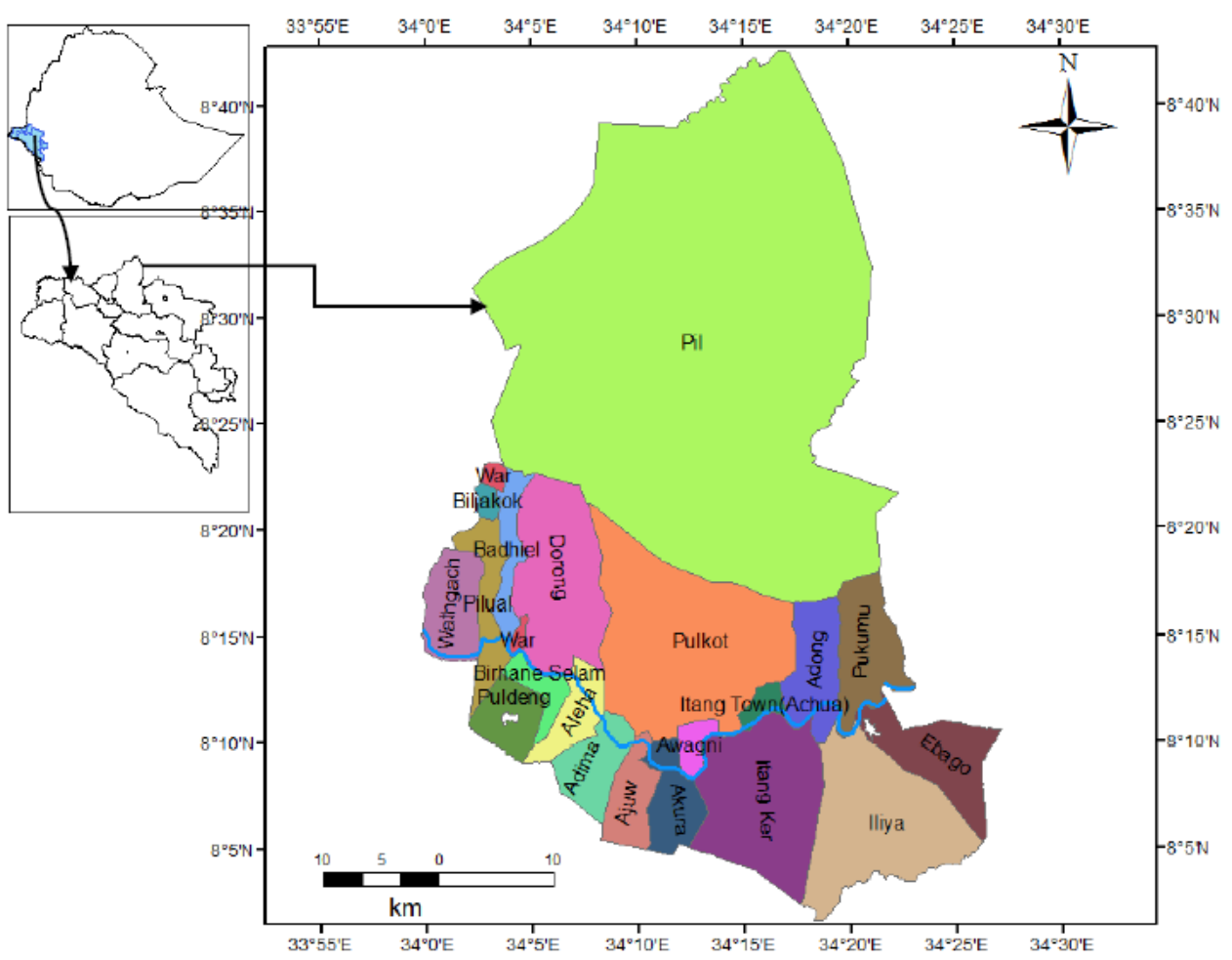

Note: The map on top of the left hand side is the country map, the bottom left map shows the region and the right hand side shows the Itang area.

Prior to 1983, the lowlands along the Baro River were virtually uninhabited. Between 1983 and 1996, however, the Ethiopian Government, in response to severe droughts in the uplands, designated the area for resettlement. Several refugees from southern Sudan were also settled in Gambela. Ever since the villages were established, they have had to deal with occasional extreme floods affecting agricultural land and human settlements in the basin (see Woube, 1999).

During high flow period, overflows of the Baro River usually inundate parts of Itang in August and September. In addition, flush floods due to the excess rainfall may occur in the same period. Figure 2 shows the number of people in Itang that were affected by flood events between 2006 and 2011, with the 2007 flood affecting most people (37\% of the population). 
Figure 2 Flood affected population in Gambella region and Itang area during 2006-2011, where 2009 is a drought year (see online version for colours)

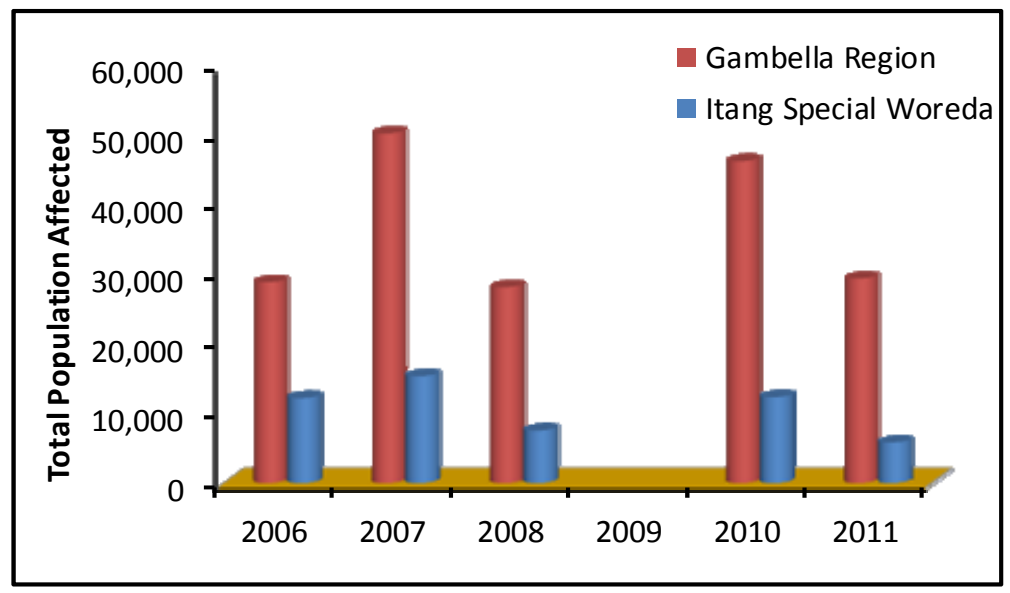

Source: DPFSA (2012)

\section{Methods}

We conducted a household survey among 431 households in 19 villages between September and November, 2012. The villages are divided into a number of sub-villages. In each sub-village we applied a random sampling strategy to select the respondents, with a minimum of 12 households. Community members helped us to determine the total number of households in each sub-village. Next, every nth household starting from the boundary of each sub-village was surveyed in which $n$ varies from 10 to 30 depending on the total number of population.

In addition to the household survey, we conducted 20 in-depth interviews with key informants. These were both residents (namely elders and flood-affected people), and other stakeholders (particularly people working for governmental and non-governmental organisations, who have been involved in flood-related activities). The key informants provided information about the nature of flooding in different parts of Itang, characteristics of the major flood events over the past 20 years, coping and adaptation strategies of households, the most vulnerable groups, and interventions by governmental organisations and non-governmental organisations (NGOs). We organised four focus group discussions with:

1 a mixed group consisting of experts such as teachers, health officers and local government officials

2 a group of men, consisting of farmers, pastoralists, agro-pastoralist and fishermen 
3 a group of women, consisting of petty traders, house workers, farmers, pastoralists, and agro-pastoralist

4 a mixed group consisting of farmers, pastoralists, agro-pastoralist and fishermen.

In each group there was a wide variety in the age and socio-economic status of the participants. Finally, we conducted in-depth interviews with six flood-affected residents, who were selected based on recommendations by participants in the focus group discussions. These affected residents narrated their experience of the 2007 flood.

\section{Results}

\subsection{Livelihood activities}

In the study area, most people are involved in more than one economic activity (Table 1). The main activities are crop cultivation and livestock keeping. In the floodplains, farmers mainly grow maize and sorghum, practicing both rain-fed cultivation (May to August) and recession crop cultivation (immediately after the floods in mid-September). Next to this, farmers living on the riverbanks cultivate tree crops such as mango and avocado, and vegetables for their own consumption and for sale. Although fish is one of the staple foods in Itang, our survey results indicate that only few households are involved in fishing as a primary source of livelihood.

Table 1 Income generating activities in Itang

\begin{tabular}{lc}
\hline & Percentage of the total number of respondents \\
\hline No. of income generation activities & 26.6 \\
One & 51.5 \\
Two & 19.8 \\
Three & 1.4 \\
Four & 0.5 \\
Five & 0.2 \\
Six & \\
Main source of income or food & 82.1 \\
Crop cultivation & 10.7 \\
Livestock keeping & 0.2 \\
Fishing & 1.9 \\
Trading & 4.9 \\
Salary work & 0.2 \\
Labour &
\end{tabular}

Source: Household survey 2012 


\subsection{The 2007 extreme flood}

The 2007 flood of the Baro River was caused by heavy rainfall in the study area and upstream areas. It lasted for more than eight weeks (in some places up to 12 weeks), extending over the two main crop-growing seasons, and substantially affected crop cultivation, causing local food insecurity (see the section on impact). The flood inundated the yards of about $94 \%$ of the respondents, with the water level exceeding ankle height in $60 \%$ of the cases. The floodwater also found its way into $72 \%$ of the surveyed houses. One of the main characteristics of the 2007 flood was its excessively high depth, which limited people's mobility. In many villages, swimming was the only way to cross the floodwater and access service areas, such as hospital and market places.

\subsection{Flood impact}

Many of the houses in Itang are built from wood, grasses and mud walls, which are easy to reconstruct. This in itself is a deliberate adaptation to the high likelihood of flooding. These building materials are not strong enough to withstand an extreme flood and $38 \%$ of the surveyed houses were severely damaged by the 2007 flood (Table 2). Several houses got inundated for several weeks. One quarter of the surveyed households said that, as a result, their properties were severely damaged. The 2007 flood also led to health problems and casualties. Participants in focus group discussions mentioned that many elderly people and children got sick during the 2007 flood, particularly due to diarrheal disease, caused by the intrusion of river water into wells and boreholes. Also, respondents mentioned that some children drowned while playing outside during the 2007 flood period, but we could not obtain any official figures about the number of casualties.

Table 2 The impact of the 2007 extreme flood on households

\begin{tabular}{lcccc}
\hline & No damage & Slight damage & $\begin{array}{c}\text { Severe } \\
\text { damage }\end{array}$ & $\begin{array}{c}\text { Entirely } \\
\text { destroyed }\end{array}$ \\
\hline Crops & 1.9 & 8.7 & 77.3 & 12.1 \\
Harvested and pilled crop & 35.8 & 23.1 & 38.7 & 2.3 \\
Cattle & 9.2 & 15.5 & 73.2 & 2.1 \\
Poultry & 21.8 & 24.7 & 48.5 & 5.0 \\
Food reserve & 32.5 & 18.3 & 48.1 & 1.1 \\
House & 20.3 & 41.3 & 37.9 & 0.5 \\
Household properties & 48.8 & 26.4 & 24.5 & 0.2 \\
\hline
\end{tabular}

Source: Household survey 2012

$97 \%$ of the respondents characterised the 2007 flood as either very severe or disastrous, which is mainly due to the widespread impact of the flood on people's crop production and livestock (Table 2). According to almost $90 \%$ of the respondents the flood severely damaged or destroyed their standing crops, mostly maize and sorghum of the first (rain fed) cultivation season. $41 \%$ reported that their harvested and piled grains were either severely damaged or destroyed. These losses directly affected people's food security. On top of that, about half of the respondents indicated that the flood damaged the existing reserves of grains, which exacerbated local food scarcity. 
Three out of four of the households that kept cattle and nearly half of the households with poultry reported severe damage. Many animals drowned or died due to flood-related diseases. For example, as the floodwater carried a large number of snails, animals would swallow snails while drinking, which affected their internal organs and caused them to die. Moreover, the inundation of most grazing lands caused a lack of food for the cows. $60 \%$ of the respondents reported that this negatively affected the milk production. Participants in focus group discussions mentioned that the amount of milk production reduced to less than two litres per day during the 2007 flood, while it would normally be approximately four litres per day per cow.

As the 2007 flood compromised people's access to food, people had to import foodstuffs (particularly grain) from the neighbouring Oromya region. About $85 \%$ of the respondents reported a significant increase in expenditures on food items. Moreover, three out of four respondents indicated that the flood severely limited their possibilities to engage in other income earning activities, because the lands were inundated.

The impact of the 2007 flood was not limited to the months of the flood - it also negatively affected the production of the second cropping season in the area. The river overflow lasted longer than usual, and therefore overlapped with the period of recession crop cultivation. In response, $12 \%$ cancelled the second cropping, $16 \%$ changed the type of crop (e.g., cultivating vegetables instead of maize), and 13\% decided to invest less labour and land for the cultivation of the second crop. Also, 13\% indicated to have delayed sowing, which extended the growing season into the driest month (January), negatively affecting crop yields. In total, $85 \%$ of the respondents stated that the flood severely decreased the production of the second crop.

\subsection{Coping after the flood}

Immediately after the 2007 flood, affected households received assistance from NGOs, the government and religious organisations. NGOs like UNICEF, ZOA, and the World Food Program played an important role in assisting up to three out of four of the surveyed households. This assistance was mostly in the form of food and material aid. Many households received a $50 \mathrm{~kg}$ bag of grain soon after the flood had occurred. Also, the government provided temporary shelters in Achua village, which were used by $39 \%$ of the respondents. These government shelters, however, were overcrowded, with up to 50 people living in a single room, which led to incidences of some diseases like diarrhoea. While staying at the government-provided shelters, people were relying on neighbours, relatives and friends, particularly for food and financial assistance. And, as the shelters were overcrowded, many people ended up staying with their relatives living in non-affected areas. Approximately $50 \%$ of the surveyed households mentioned that they relied on their social network to deal with the 2007 flood impact (Table 3).

Almost $37 \%$ of the households received financial assistance from within their social networks - either by borrowing money (without having to pay interest) or receiving financial gifts. In addition, many people received food and material assistance. Some affected households received a cow from relatives, to provide milk for consumption and sale. Others received meat from neighbours or relatives, which was then dried for preservation so that it served as a food reserve to be used over the extended flood season. Also, as the food prices were high due to the local shortage of grains immediately after the flood, neighbours and friends would organise themselves to pool money, enabling 
them to collectively buy a quintal of maize, which was then divided among the participating households.

Table 3 Received support to cope with the impacts of the 2007 flood

\begin{tabular}{lcccccc}
\hline \multirow{2}{*}{$\begin{array}{l}\text { Sources of } \\
\text { support }\end{array}$} & $\begin{array}{c}\text { \% of households } \\
\text { that received } \\
\text { any support }\end{array}$ & Shelter & $\begin{array}{c}\text { Financial } \\
\text { gifts }\end{array}$ & $\begin{array}{c}\text { Money } \\
\text { borrowed }\end{array}$ & $\begin{array}{c}\text { Food } \\
\text { assistance }\end{array}$ & $\begin{array}{c}\text { Material } \\
\text { assistance }\end{array}$ \\
\cline { 3 - 7 } & 50.2 & 8.5 & 9.2 & 27.4 & 21.0 & 9.9 \\
\hline $\begin{array}{l}\text { Social network } \\
\begin{array}{l}\text { Government } \\
\text { agency }\end{array}\end{array}$ & 38.1 & 18.7 & 0.0 & 0.2 & 25.4 & 12.9 \\
NGO & 75.5 & 13.4 & 0.2 & 4.0 & 66.1 & 53.5 \\
$\begin{array}{l}\text { Religious } \\
\text { organisation }\end{array}$ & 31.1 & 1.7 & 1.0 & 0.7 & 16.5 & 26.5 \\
\hline
\end{tabular}

Source: Household survey 2012

Financial assistance appeared particularly important, both for the purchase of food and medical care for flood-related diseases, and to enable people to get engaged in income-earning activities. Households would, for example, use the money they received to buy raw materials for making local drinks from grains (Areke and Borde), which they then sold. This income helped them to cope with the adverse impacts of the flood. Households who did not have adequate access to financial assistance were forced to sell part of their properties, like livestock ( $42 \%$ of the households). Such coping strategies erode the asset base of households, which may lead to increased vulnerability to impacts of future floods.

Both the survey results and the information from qualitative research methods highlight the importance of social networks in dealing with the impacts of extreme floods. Participants in focus group discussions pointed out, however, that there is a limit to the level of reliance on social networks in the study area, since:

1 relatives and neighbours have limited resources to support the flood affected people

2 flood affected people do not feel comfortable with repeatedly receiving material or financial assistance from their social network or staying with their relatives for a longer period of time.

We found that many people were worried about over-using their social networks, especially with floods occurring more frequently.

Despite the above-mentioned coping measures and received assistance, $78 \%$ of the respondents stated that they had to substantially reduce their food expenses after the 2007 flood. During group discussions participants stressed that this increased the vulnerability of people to flood-related diseases such as malaria and diarrhoea. Overall, $95 \%$ of the respondents who took coping measures said that their coping measures had not been enough to deal with the impact of the 2007 extreme event.

\subsection{Preventive measures}

In addition to the coping measures - which were adopted immediately after the flood, in order to deal with its immediate consequences - we identified a range of measures that people took before the flood occurred, in order to avoid or reduce the negative impacts. 
We found that all the surveyed households in the study area had adopted one or more of such preventive measures (Table 4).

Table 4 Prevention measures to reduce the impact of the 2007 flood

\begin{tabular}{|c|c|c|c|}
\hline \multirow[t]{2}{*}{ Preventive action } & \multirow{2}{*}{$\begin{array}{c}\text { Adapted } \\
\text { measure } \\
\text { (\% of } \\
\text { respondents) }\end{array}$} & \multicolumn{2}{|c|}{$\begin{array}{l}\text { Reduced or avoided the } \\
\text { flood impact (\% of those } \\
\text { who adapted the measure) }\end{array}$} \\
\hline & & $\begin{array}{l}\text { Slightly } \\
\text { reduced }\end{array}$ & $\begin{array}{c}\text { Fully } \\
\text { avoided }\end{array}$ \\
\hline \multicolumn{4}{|l|}{ To prevent inundation of houses } \\
\hline Increasing floor height & 73.5 & 59.2 & 0.3 \\
\hline Make boundary wall & 79.8 & 48.4 & 0.6 \\
\hline Keep ditches clean & 40.6 & 25.3 & 0.6 \\
\hline Dig new ditches & 38.2 & 36.8 & 5.5 \\
\hline \multicolumn{4}{|c|}{ To protect household properties from flood damage } \\
\hline Elevate (e.g., under rooftop) & 66.7 & 62.9 & 18.6 \\
\hline Shift to relative's house & 34.2 & 62.0 & 4.2 \\
\hline Keep on floating objects & 7.0 & 42.9 & 3.6 \\
\hline Sell properties & 9.0 & 71.4 & 0.0 \\
\hline \multicolumn{4}{|c|}{ To protect standing crops from flood damage } \\
\hline Harvest premature crops & 29.1 & 52.2 & 0.0 \\
\hline Keep ditches clean & 32.1 & 17.3 & 1.6 \\
\hline Dig new ditches & 40.8 & 29.5 & 6.0 \\
\hline \multicolumn{4}{|l|}{ To protect cattle } \\
\hline Construct high stage & 47.3 & 62.5 & 0.9 \\
\hline Bring to dry place in Itang & 54.9 & 74.6 & 3.8 \\
\hline Bring to area outside Itang & 16.8 & 51.4 & 2.9 \\
\hline Selling cattle & 44.9 & 70.3 & 0.0 \\
\hline \multicolumn{4}{|c|}{ To protect fowls from flood damage } \\
\hline Construct high stage & 59.8 & 63.1 & 16.8 \\
\hline Bring to dry place in Itang & 20.2 & 72.9 & 4.2 \\
\hline Bring to area outside Itang & 7.4 & 62.5 & 0.0 \\
\hline Floating objects & 5.1 & 40.0 & 0.0 \\
\hline Selling fowls & 21.5 & 81.3 & 2.1 \\
\hline
\end{tabular}

Source: Household survey 2012

$80 \%$ reported the construction of boundary walls around their houses. These walls are made from mud, and usually reach up to ankle height. None of the respondents, however, said this measure had been sufficient to avoid impact of the 2007 flood. Raising the floor level of the house appeared another common long-term prevention measure, reported by $74 \%$ of the respondents. Higher floor levels suffice to prevent negative impacts of normal floods, but did not help much during the 2007 extreme flood. Close to $40 \%$ of the respondents indicated to have created ditches around their house and farmlands in order to divert the water away from their property, but only about $5 \%$ of the respondents felt 
that these ditches were helpful during the 2007 flood. The low effectiveness of ditches is explained by the fact that they are often small and have a low gradient, due to the flatness of area.

In 2007, the water level of the Baro River gradually increased over a period of weeks. Observing the river, people anticipated a higher level and longer duration of the flood than usual. In response, some people decided to take short-term preventive measures to reduce damage on standing crops. $29 \%$ of the interviewed farmers, for example, harvested their crops prematurely. None of the respondents mentioned that these measures helped them to fully avoid the flood impact on the standing crops.

Another important short-term prevention measure was the relocation of cattle to safe areas. Nearly half of the respondents with large animals (cows, sheep and goats) brought their cattle to a raised stage or to higher locations, often near schools and stores. $17 \%$ of the households that kept cattle eventually evacuated them outside the Itang area. Keeping cattle on relatively dry and high elevation places helped to reduce the direct impact of the flood, but did not prevent the impact of the flood on the availability of grazing land. This explains that only few of the respondents (about 3\%) stated that these measures were helpful in fully avoiding the impact of floods on animals. The preventive actions to protect fowls were similar, although fewer farmers were eventually forced to evacuate their fowls, as it was easier to keep them on raised stages. In addition to bringing animals to dry places, $55 \%$ of the respondents opted to sell (part of) their cattle in anticipation of the flood.

Households also took preventive measures to reduce damage to household properties. Two-thirds of the households moved properties to an elevated place within their own house. As the flood level increased and the threat became more serious, $34 \%$ of the respondents decided to shift their properties to the house of a relative living in an area that was not affected by the flood. In this way, people were able to save at least part of their properties, depending upon the number of household members who could help with carrying and the travel distance to the temporary shelters.

\subsection{Vulnerability}

As mentioned in the introduction, differences may exist in the way people respond to extreme events and the success of these measures, depending on certain household characteristics, including education levels, livelihood sources, and income. When we compared the extent to which households were still experiencing negative effects despite their measures, we found a significant difference between single-headed households and other households (Table 5). This result is in line with perception of the focus group discussion participants who stated that particularly widows are vulnerable to the floods.

The importance of educational and income levels of the respondents in avoiding negative effects was not clearly observed. This is probably because the differences in income and education levels are very low in the research area. However, we found a strong relation between the main source of livelihood and the success of measures taken to avoid negative flood effects. Overall, respondents who relied on crop cultivation as their main source of livelihood were less successful (64\% reported severe effect) in avoiding severe negative effects than those who mainly relied on livestock keeping ( $47 \%$ reported severe effect). This is mostly explained by the mobility of livestock, enabling farmers to relocate their animals to higher located places. 
Table 5 Respondents' perceptions about the success of measures to deal with the 2007 flood

\begin{tabular}{lccc}
\hline & $\begin{array}{c}\text { Monogamous } \\
\text { marriage } \\
(n=142)\end{array}$ & $\begin{array}{c}\text { Polygamous } \\
\text { marriage } \\
(n=115)\end{array}$ & $\begin{array}{c}\text { Single headed* } \\
(n=153)\end{array}$ \\
\hline Still severe negative effects & $57 \%$ & $56 \%$ & $74 \%$ \\
Still moderate negative effects & $38 \%$ & $38 \%$ & $25 \%$ \\
It allows us to carry on & $5 \%$ & $5 \%$ & $1 \%$ \\
It has even improved our situation & $0 \%$ & $1 \%$ & $0 \%$ \\
Total & $100 \%$ & $100 \%$ & $100 \%$ \\
\hline
\end{tabular}

Note: *Widowed, divorced, never married

\section{Discussion}

\subsection{External support and social capital}

Paul and Routray (2010) found that external support combined with social capital (i.e., networks and interactions among people) can significantly improve the capacity of people to deal with floods. Our research results confirm the importance of external support and social networks. To deal with the negative impacts of the 2007 flood, people in Itang largely depended on assistance from outside, in the form of relief assistance by government agencies, NGOs and religious organisations. These organisations provided essential support in terms of food and shelter, but this served only as short-term relief. In addition to emergency assistance, social networks - people's relatives, friends and neighbours - were important for half of the surveyed households. These social networks provided, for example, access to financial resources to flood-affected people, who used these to invest in productive activities such as the production of drinks for sale. Investments in such non-farm activities provided longer-term livelihood security to the affected households, enabling them to earn some income during the flood period.

Although support from people's social networks enabled affected households to cope with the flood effects, many respondents stressed its limitations. They indicated to feel increasingly uncomfortable with depending on the assistance of their social network for too long (in the case of extended excessive floods periods), or too often (in the case of recurrent excessive floods). They argued that the willingness and capacity of their friends and relatives could be over-used and, finally, exhausted. Hence, rather than increasing people's coping capacity to deal with increased frequency and intensity of floods, heavy dependence on social capital runs the risk of eroding people's coping capacity. As such, it may eventually increase people's vulnerability to climate change in the long term.

\subsection{Interventions to minimise flood impacts}

In present-day Itang, people's capacity to cope with extreme floods is limited, and floods tend to have a long-term negative effect on local livelihoods. Farmers can do little to protect the crops when the water level is rising, so an extreme flood may result in a completely failed harvest. Moreover, farmers are generally not able to sow new crops soon after the flood, because the soils are too wet. They therefore have to delay the 
sowing, which means the crop season extends into the dry season, resulting in a lack of water during the crop's maturity stage. Here the introduction of small-scale irrigation systems could help to prevent crop failure. Alternatively, the cultivation of quickly maturing vegetables, like tomatoes and potatoes, is a good option for farmers after an excessive flood, as it allows them to harvest before the dry period starts. Extension services can help farmers to access vegetable seeds. Another avenue to enhance people's coping capacity is through improving access to micro-finance services. This would enable people to invest in (temporary or long-term) non-farm income earning activities, which would make them less vulnerable to crop failures due to extreme floods.

Our findings show that the effectiveness of people's long-term and ad hoc preventive strategies is limited in the case of extreme floods. This suggests there is a need for government investments in structural preventive measures. Such measures could include the construction of wide drainage canals, dykes and flood retention basins. Also, the incidence of flood-related diseases can be reduced by increasing access to safe water supplies and sanitary facilities, and by raising people's awareness of the risks of contamination during flood periods.

Another, more drastic type of prevention strategy would be the resettlement of people, away from flood-prone areas. The Ethiopian government has already started a voluntary 're-villagisation' (resettlement) project, which involves voluntary movement of people from flood prone areas to new villages that are supposed to have a lower risk of flooding and at the same time allow crop cultivation. We found that many respondents were not eager to move to another village. The newly established villages, according to them, have security problems (conflicts over natural resources) and a lack of services such as health facilities. Moreover, people said there were major flood events in the new villages as well, questioning the benefit of moving from one flood prone area to another one.

\section{Conclusions}

People in Itang area, Gambela Region, Ethiopia, coped with the effects of the 2007 flood by relying heavily on short-term external assistance of governmental and non-governmental agencies. In addition, many people made use of their social networks, for example to access financial resources to make small-scale productive investments. This helped them through the extended flood period, during which they could not farm because the lands were inundated. Many flood-affected respondents, however, were worried about draining their social network, which suggests there are limitations to people's access to social capital.

Despite a wide range of prevention and coping measures, the 2007 extreme flood event resulted in severe negative impacts, both on standing crops and livestock, as well as on future agricultural production. We found that single-headed households are the most vulnerable. The coping strategies adopted by the people in the study area do not lead to long-term adaptation, but are more likely to erode coping capacity. To limit negative impacts of extreme floods in the future, there is a need to strengthen people's coping capacity through investments that help to widen their agricultural and non-agricultural options. Next to that, investments in preventive measures that exceed the household-level are required, particularly in the form of larger-scale flood preventing infrastructure. 


\section{Acknowledgements}

This project was funded by the United Nations Economic Commission for Africa, African Climate Policy Centre. Some support was also received from the IMPACT2C project of the International Water Management Institute (IWMI) particularly during preparation of the article. We also highly appreciate the help provided by Dr. Kees van der Geest in framing the research and developing data collection tools.

\section{References}

Abaya, S.W., Mandere, N. and Ewald, G. (2009) 'Floods and health in Gambella region, Ethiopia: a qualitative assessment of the strengths and weaknesses of coping mechanisms', Global Health Action, Vol. 2, pp.1-10.

Bryan, E., Deressa, T.T., Gbetibouo, G.A. and Ringler, C. (2009) 'Adaptation to climate change in Ethiopia and South Africa: options and constraints', Environmental Science and Policy, Vol. 12, No. 4, pp.413-426.

Burton, I. (1997) 'Vulnerability and adaptive response in the context of climate and climate change', Climate Change, Vol. 36, Nos. 1-2, pp.185-196.

Conway, D. and Schipper, E.L.F. (2011) 'Adaptation to climate change in Africa: challenges and opportunities identified from Ethiopia', Global Environmental Change, Vol. 21, pp.227-237.

Del Ninno, C., Dorosh, P.A. and Smith, L.C. (2003) 'Public policy, markets and household coping strategies in Bangladesh: avoiding a food security crisis following the 1998 floods', World Development, Vol. 31, No. 7, pp.1221-1238.

DPFSA (2012) Report of the Regional Emergency Coordination Forum Task Force, August, Gambella, Ethiopia (Unpublished).

Gray, C. and Mueller, V. (2012) 'Drought and population mobility in rural Ethiopia', World Development, Vol. 40, No. 1, pp.134-145.

Hernández-Guerrero, J., Vieyra-Medrano, A. and Mendoza, M.E. (2012) 'Adaptation strategies in communities under precarious housing: flooding risks in the peri-urban sector of the city of Morelia, Michoacán, México', Applied Geography, Vol. 34, pp.669-679.

IPCC (2007) Climate Change 2007: The Physical Science Basis. Contribution of Working Group I to the Fourth Assessment Report of the Intergovernmental Panel on Climate Change, 996p, Solomon, S., Qin, D., Manning, M., Chen, Z., Marquis, M., Averyt, K.B., Tignor, M. and Miller, H.L. (Eds.), Cambridge University Press, Cambridge, UK and New York, NY, USA.

IPCC (2012) Managing the Risks of Extreme Events and Disasters to Advance Climate Change Adaptation. A Special Report of Working Groups I and II of the Intergovernmental Panel on Climate Change, 582p, Field, C.B., Barros, V., Stocker, T.F., Qin, D., Dokken, D.J., Ebi, K.L., Mastrandrea, M.D., Mach, K.J., Plattner, G-K., Allen, S.K., Tignor, M. and Midgley, P.M. (Eds.), Cambridge University Press, Cambridge, UK, and New York, NY, USA.

Lazarus, N.W. (2011) 'Coping capacities and rural households: challenges to community risk management in Southern Sri Lanka', Applied Geography, Vol. 31, No. 1, pp.20-34.

Linnekamp, F., Koedam, A. and Baud, I.S.A. (2011) 'Household vulnerability to climate change: examining perceptions of households of flood risks in Georgetown and Paramaribo', Habitat International, Vol. 35, No. 30, pp.447-456.

McCann, D.G.C., Moore, A. and Walker, M-E. (2011) 'The water/health nexus in disaster medicine: I. Drought versus flood', Current Opinion in Environmental Sustainability, Vol. 3, No. 6, pp.480-485.

McGuire, S.J. and Sperling, L. (2008) 'Leveraging farmer's strategies for coping with stress: Seedaid in Ethiopia', Global Environmental Change, Vol. 18, No. 4, pp.679-688. 
Nyakundi, H., Mogere, S., Mwanzo, I. and Yitambe, A. (2010) 'Community perceptions and response to flood risks in Nyando District, Western Kenya', Journal of Disaster Risk Studies, Vol. 3, No. 1, pp.346-365.

Paul, S.K. and Routray, J.K. (2010) 'Flood proneness and coping strategies: the experiences of two villages in Bangladesh', Disasters, Vol. 34, No. 2, pp.489-508.

Pauw, K., Thurlow, J. and van Seventer, D. (2010) Droughts and Floods in Malawi, Assessing the Economy Wide Effects, IFPRI Discussion Paper 00962.

Smithers, J. and Smit, B. (1997) 'Human adaptation to climate variability and change', Global Environmental Change, Vol. 7, No. 3, pp.129-146.

Tarekegn, T.H., Haile, A.T., Rientjes, T., Reggiani, P. and Alkema, D. (2010) 'Assessment of an ASTER-generated DEM for 2D hydrodynamic flood modeling', International Journal of Applied Earth Observation and Geoinformation, Vol. 12, No. 6, pp.457-465.

Warner, K., van der Geest, K., Kreft, S., Huq, S., Kusters, K. and de Sherbinin, A. (2012) Evidence from the Frontlines of Climate Change: Loss and Damage to Communities Despite Coping and Adaptation, Loss and Damage in Vulnerable Countries Initiative, Policy Report, Report No. 9, United Nations University Institute for Environment and Human Security (UNU-EHS), Bonn.

Woube, M. (1999) 'Flooding and sustainable land-water management in the lower Baro-Akobo river basin, Ethiopia', Applied Geography, Vol. 19, pp.235-251. 